\title{
Glacier retreat on South Georgia and implications for the spread of rats
}

\author{
A.J. COOK ${ }^{1}$, S. PONCET ${ }^{2}$, A.P.R. COOPER ${ }^{1}$, D.J. HERBERT ${ }^{1}$ and D. CHRISTIE ${ }^{3}$ \\ ${ }^{I}$ British Antarctic Survey, NERC, High Cross, Madingley Road, Cambridge CB3 OET, UK \\ ${ }^{2}$ South Georgia Surveys, PO Box 756 Stanley, Falkland Islands FIQQ 1 ZZ \\ ${ }^{3}$ Government of South Georgia and the South Sandwich Islands (GSGSSI), Government House, Stanley, Falkland Islands \\ acook@bas.ac.uk
}

\begin{abstract}
Using archival photography and satellite imagery, we have analysed the rates of advance or retreat of 103 coastal glaciers on South Georgia from the 1950s to the present. Ninety-seven percent of these glaciers have retreated over the period for which observations are available. The average rate of retreat has increased from $8 \mathrm{Ma}^{-1}$ in the 1950 s to $35 \mathrm{Ma}^{-1}$ at present. The largest retreats have all taken place along the north-east coast, where retreat rates have increased to an average of $60 \mathrm{Ma}^{-1}$ at present, but those on the south-west coast have also been steadily retreating since the 1950s. These data, along with environmental information about South Georgia, are included in a new Geographic Information System (GIS) of the island. By combining glacier change data with the present distribution of both endemic and invasive species we have identified areas where there is an increased risk of rat invasion to unoccupied coastal regions that are currently protected by glacial barriers. This risk has significant implications for the surrounding ecosystem, in particular depletion in numbers of important breeding populations of groundnesting birds on the island.
\end{abstract}

Received 5 August 2009, accepted 10 December 2009

Key words: ecosystem, GIS, invasive species, sub-Antarctic

\section{Introduction}

The sub-Antarctic island of South Georgia lies between $35^{\circ} 50^{\prime}-38^{\circ} \mathrm{W}$ and $54^{\circ}-54^{\circ} 55^{\prime} \mathrm{S}$, just south of the Polar Front (Fig. 1). It is approximately $170 \mathrm{~km}$ long and up to $40 \mathrm{~km}$ wide. The landscape is mountainous, with eleven peaks above $2000 \mathrm{~m}$, the highest being Mount Paget at $2934 \mathrm{~m}$. Glaciers, ice caps and snowfields cover over $50 \%$ of the island, leaving a narrow coastal fringe of vegetation that is snow-covered in winter. The island's location in the Southern Ocean makes it an important breeding site for an estimated 30 million pairs of seabirds, notably penguins, albatrosses and petrels, and over 3 million fur seals and 100000 elephant seals. Its rich biodiversity makes the island unique and of worldwide importance.

South Georgia also has a long history of human exploitation, starting soon after its discovery by Captain James Cook in 1775 , and during the first half of the 20th century it supported several whaling stations. During this period rats (Rattus norvegicus (Berkenhout)), reindeer (Rangifer tarandus L.), mice (Mus musculus L.) and a number of invasive species of plants and invertebrates were introduced to the island, either accidentally or deliberately (Frenot et al. 2005). Of these invasive species, rats pose the greatest threat to birds, as they are active predators of the eggs and young of burrow-nesting petrels (e.g. common diving petrels (Pelecanoides urinatrix exsul Salvin), South Georgia diving petrels (Pelecanoides georgicus Murphy \& Harper), Antarctic prions (Pachyptila desolata Gmelin) and blue petrels (Halobaena caerulea Gmelin)) and ground-nesting passerines and waterfowl (e.g. the South Georgia pipit (Anthus antarcticus Cabanis) and yellow-billed pintail (Anas georgica georgiana Gmelin)) (Pye \& Bonner 1980, Moors 1985, Prince \& Poncet 1996, Poncet 2000). Rats are restricted principally to coastal areas of tussac and Festuca grasslands (Pye \& Bonner 1980, Poncet 2000, Pasteur \& Walton 2006). These are the dominant plant communities on the island, and cover a large proportion of the non-glaciated coastal areas of South Georgia.

Previous glaciological research carried out on South Georgia has shown a general pattern of glacial advance and retreat over time: a period of advance in the late 19th century Little Ice Age was followed by a recession, then another advance in the early 20th century and finally the current period of recession (Hayward 1983, Clapperton et al. 1989, Gordon \& Timmis 1992, Gordon et al. 2008). The climate records from South Georgia (recorded at King Edward Point from 1905 until 1988, and subsequently from 2001 until 2008) show that in the early 1900s the summer temperatures were relatively high (average $4.9^{\circ} \mathrm{C}$ ), lower between the 1920 s to the $1940 \mathrm{~s}$ (average $4.3^{\circ} \mathrm{C}$ ), and higher from the 1950s to the present (average $5.1^{\circ} \mathrm{C}$ ) (Fig. 2).

Early last century, most of South Georgia's glaciers reached the sea, subdividing the coastline into a series of discrete areas of potential rat habitat. Each area was bounded by an ice barrier that would have been impassable to rats (Robertson \& Gemmell 2004). These barriers 


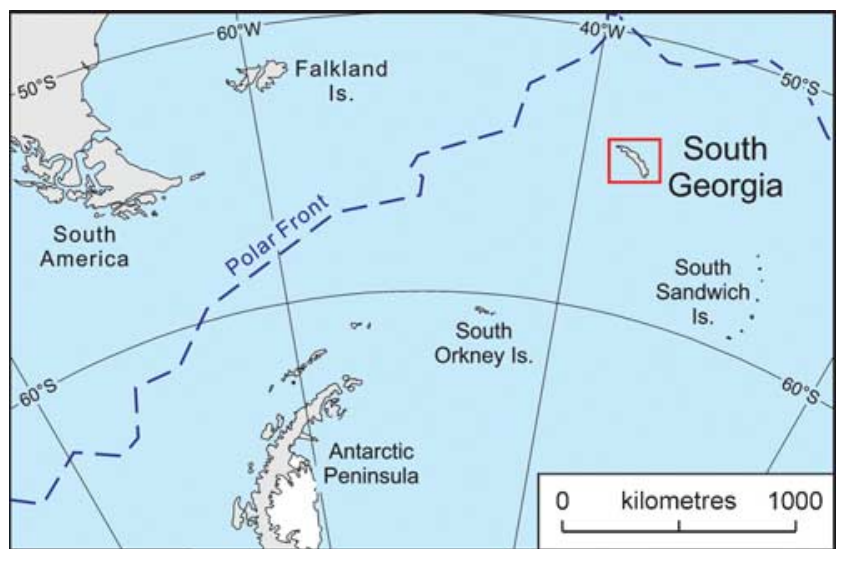

Fig. 1. South Georgia location map.

protected large parts of the coast of South Georgia from colonization by rats. This study presents evidence of widespread retreat of these glaciers, and examines the impact this may have on rat distribution on the island.

\section{South Georgia environment data}

The South Georgia Geographic Information System (SGGIS www.sggis.gov.gs), created by the British Antarctic Survey (BAS) for the Government of South Georgia and South Sandwich Islands (GSGSSI), contains data about the wildlife of South Georgia, its human history and changing physical environment. The web-based database is used to aid effective environmental management of the island and for analysing the combined datasets for patterns of change.

Many of the layers included in the GIS were from datasets compiled for a recent BAS 1:200000 scale map (BAS Misc 12A 2004), including topographic features, bathymetry and toponymy. Other layers, such as vegetation, were interpreted and digitised from Landsat images, with many additions based

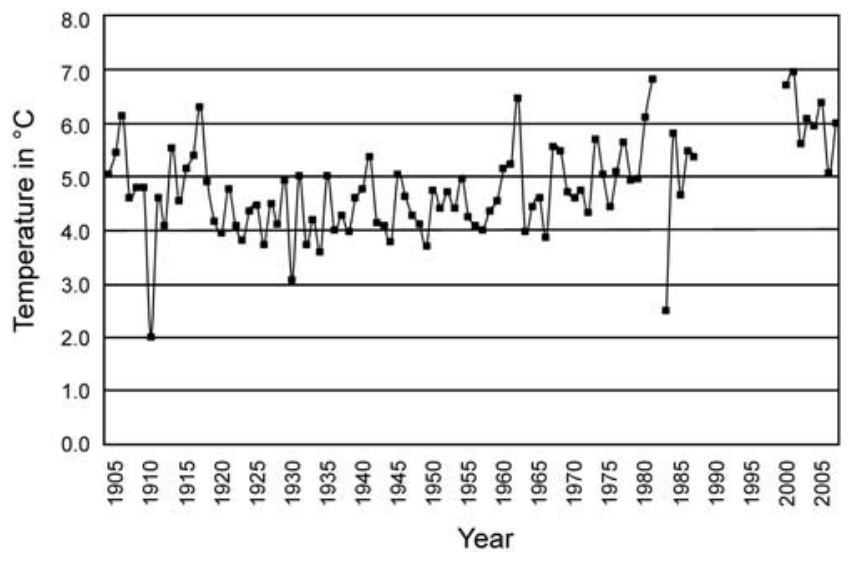

Fig. 2. Average summer temperatures on South Georgia (recorded at Grytviken, Thatcher Peninsula) (data from Turner et al. 2004). on personal knowledge by S. Poncet. Survey information also contributed to the datasets, for example, habitat boundaries were interpreted from data collected during the South Georgia Breeding Birds Survey 1985-88 and an Environmental Baseline Survey carried out in 1999-2002 (Scott \& Poncet 2003). The wildlife data, including the locations of penguin colonies, albatrosses and ground-nesting birds, were based on surveys carried out by S. Poncet and BAS between 1985 and 2007 (e.g. Poncet et al. 2006).

Knowledge about invasive species on South Georgia is primarily anecdotal due to the remoteness and scale of the location. The data held in the SGGIS for rat distribution are based on presence/absence information collected during the South Georgia Breeding Birds Survey 1985-88 and subsequent surveys (Poncet 2000). The rat distribution layer in the GIS represents areas where rats could potentially live long-term, forage or use as access routes to adjoining areas of suitable habitat. Polygons were created for rock and vegetation below $200 \mathrm{~m}$, these being considered to be areas containing suitable habitat for rats. This height was chosen based on the evidence that there is little or no tussac grass above $200 \mathrm{~m}$ and that above this height the temperature is too low for rats to survive for long enough to transit from one area to another.

As part of the GIS, we compiled a dataset that showed the changing positions of 103 coastal glacier fronts on South Georgia, using aerial photographs and satellite images dating from the 1950s to the present. We measured the changing positions of the glacier fronts to give results for both changes in overall length and in rates of retreat. Using the GIS we analysed these changes alongside rat presence data gathered from field surveys.

\section{Glacier front changes}

\section{Data sources and method}

The approach for mapping glacier front changes on South Georgia was the same as that described in detail in Cook et al. (2005). All of the ice fronts were mapped onto a common satellite image base: Landsat ETM+ Path:206 Row:098, 7 February 2003. All available relevant sources were examined and where glacier fronts were visible, these were digitised. Metadata included a reliability rating based on the accuracy of the original source. The sources consisted primarily of Royal Navy aerial photographs, which were flown at frequent intervals from the 1950 s to the present. Satellite image scenes were also used, including SPOT imagery (1990), Landsat ETM+ (2003), Envisat ASAR (2004-06), ASAR WSM (2008), and Quickbird (2006-08). For the earlier years, a 1957 Directorate of Overseas Surveys (DOS) map of South Georgia (scale 1:200000), and panoramic hand-held photographs taken on survey expeditions between the 1950s and 1970s were used. The source material did not 


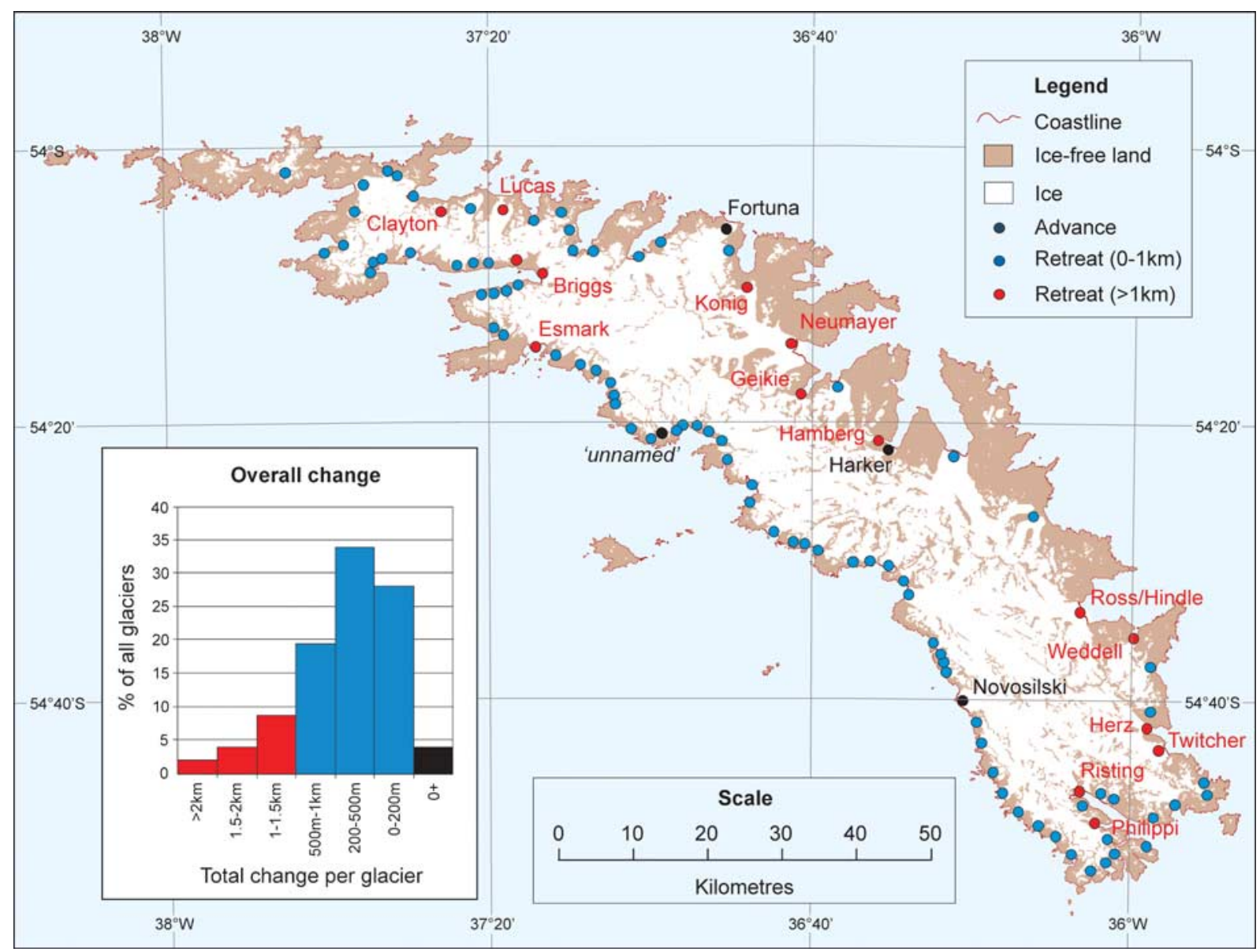

Fig. 3. Change in glacier length since earliest records (typically1950s). NB names refer to glaciers of significance: those that have advanced, or those that have retreated over $1 \mathrm{~km}$.

allow the capture of ice front changes at uniform intervals, resulting in an irregular number of ice fronts and time periods between each of the glaciers measured. In order to make an unbiased comparison between the glaciers, the ice fronts were analysed and averaged into 5-year time intervals before rates of change were calculated (see Cook et al. 2005 for method).

The resulting database contains the frontal positions for 103 coastal glaciers on South Georgia. These are defined as glaciers that terminate on or near the coast, and include ice fronts whose source may consist of more than one glacier. It does not signify the total number of glaciers on the island, but it is a comprehensive study of all glaciers on South Georgia for which there is source material available.

\section{Patterns of glacier change}

The glacier changes are presented in Fig. 3. Of the 103 coastal glaciers measured on South Georgia, 99 (97\%) have retreated since their earliest recorded position in this study. It should be noted that the earliest records varied from 1938 to 1995 , but the majority ( $84 \%$ ) were from the 1950 s. The majority $(64 \%)$ of glaciers have only retreated by between
0 and $500 \mathrm{~m}$ since their first observations. There are significant differences between glaciers along the northeast coast of the island and the south-west coast. Of the 103

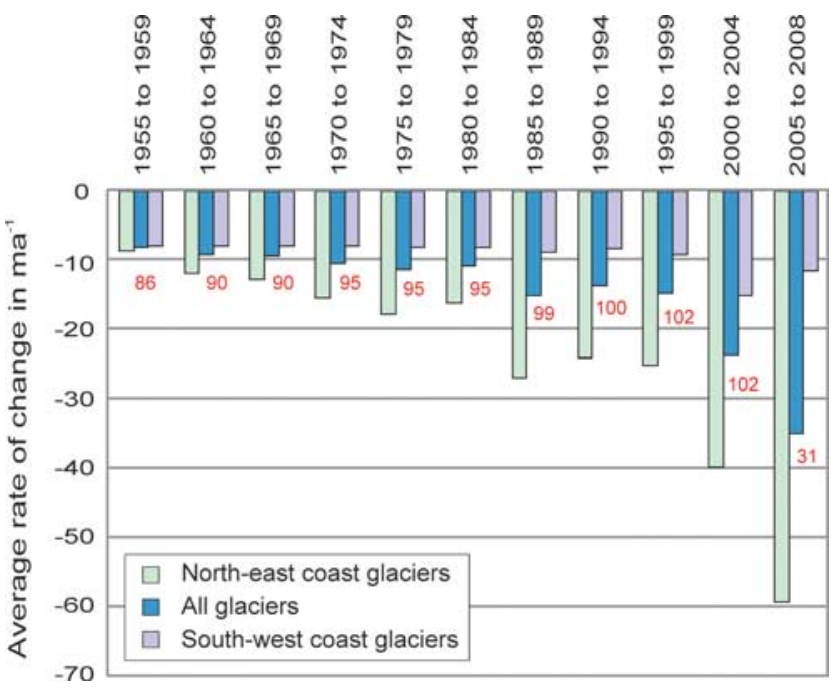

Fig. 4. Mean rates of change across all glaciers since 1950 s. Number of glaciers contributing to average is shown in red. 

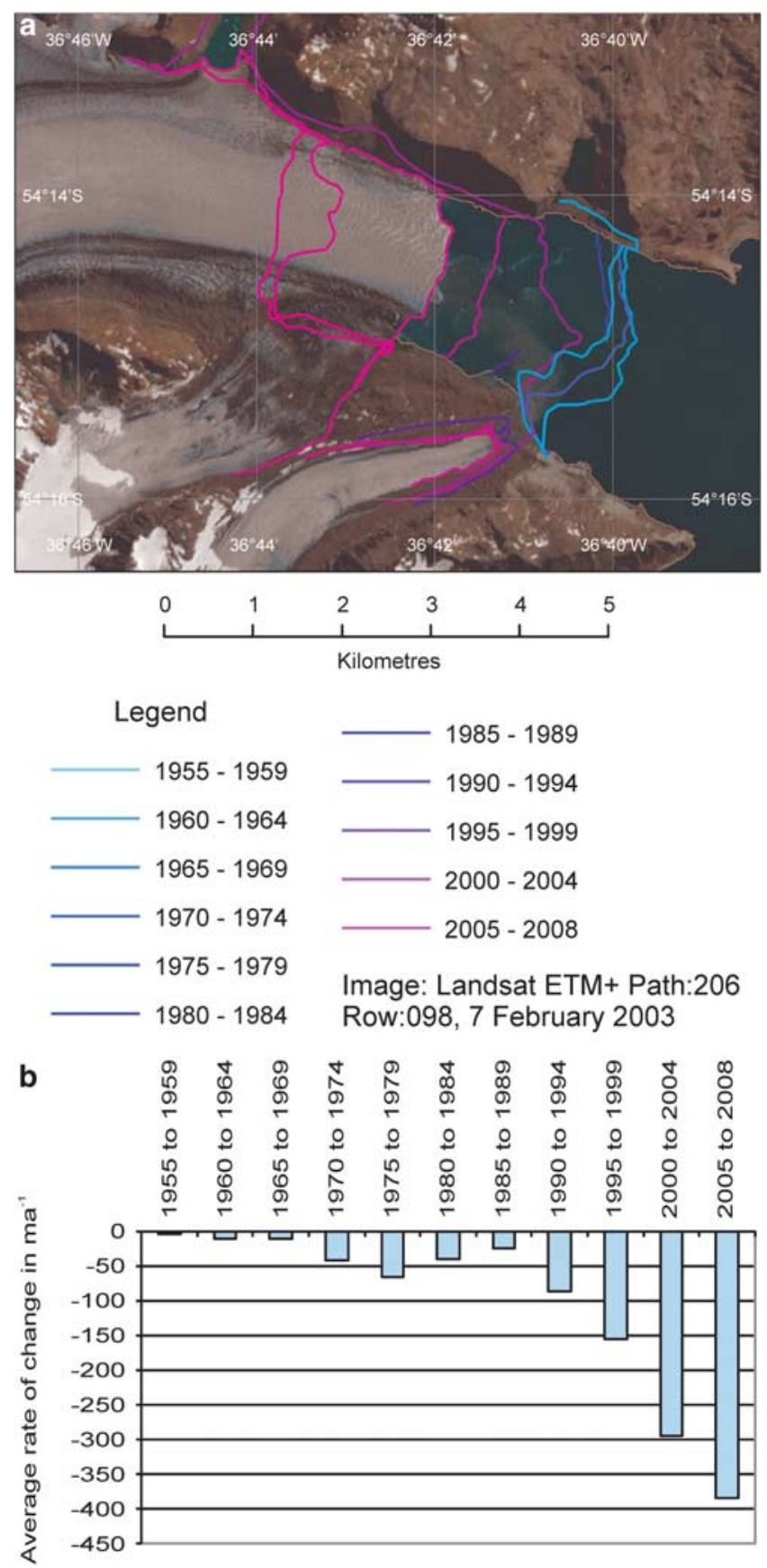

Fig. 5. a. Neumayer Glacier front positions since 1955 .

b. Neumayer Glacier mean rates of change since 1955 .

glaciers, the majority (65) occur along the south-western shore. These are smaller and narrower than the 38 glaciers which are spaced out along the north-eastern coast. A total of fifteen glaciers have retreated by over $1 \mathrm{~km}$, and ten of these lie on the north-eastern coast. Of these, two glaciers stand out as having retreated most: Neumayer Glacier by $4.4 \mathrm{~km}$ since 1957, and the ice front fed by Ross and Hindle glaciers by $2.14 \mathrm{~km}$ since 1960 . Only four ice fronts have advanced: Fortuna Glacier (64 m), Harker Glacier (37 m),
Novosilski Glacier (142 m) and a small unnamed tributary glacier flowing towards Newark Bay $(840 \mathrm{~m})$. The locations of these do not appear to be in any pattern, as all four are widely distributed across the island. There are large differences in change rates between these glaciers and they show no clear temporal trends. The unnamed glacier in Newark Bay is unique in that it has recently shown unusually high advance rates. However, this is based on only three data sources between 1992 and 2003.

Due to the differences in first and last observations between glaciers, a more accurate representation of glacier changes over time is based on rates of retreat. The rate of retreat for all 103 glaciers has increased from (on average) $8 \mathrm{ma}^{-1}$ in the late $1950 \mathrm{~s}$, to $35 \mathrm{Ma}^{-1}$ at present (Fig. 4), revealing an accelerating rate of retreat since the 1990s. The recent rapid increase in the average rate is mainly driven by large increases in retreat rates of glaciers on the north-east side of the island, which are currently showing an average of $60 \mathrm{Ma}^{-1}$ retreat. Of these, some individual glaciers have shown particularly great changes, e.g. Neumayer Glacier has increased from $3 \mathrm{Ma}^{-1}$ retreat in the late $1950 \mathrm{~s}$ to $384 \mathrm{Ma}^{-1}$ retreat at present (Fig. 5).

The glaciers along the south-west coast of the island, however, are significantly different in their rate of change. This region is defined in this study as the coastline between Cheapman Bay and Drygalski Fjord (see Fig. 6a for placenames mentioned in text). Here it is more exposed and the climate is colder, windier and wetter than the leeward north-east side. The dissimilar weather patterns caused by orographic effects can explain the differences in the scale of response between glaciers on each side of the island (Gordon \& Timmis 1992, Gordon et al. 2008). The glaciers on the south-west side have been in retreat slowly since the 1950s; this retreat remained at a constant rate of approximately $8 \mathrm{Ma}^{-1}$ (Fig. 4) until the late 1990s but may now be gradually increasing, although on a much smaller scale than on the north-east side of the island (currently $12 \mathrm{Ma}^{-1}$ ). The northeast glaciers results largely correspond to those in another recent study of 36 glaciers on South Georgia by Gordon et al. (2008), although our comprehensive study shows that the south-west glaciers are retreating, contrary to previous beliefs that many were stable or advancing (Gordon et al. 2008).

The glacial retreat over the past half-century coincides with the recent period of climate warming that began in the 1950s (Fig. 2). Acceleration in retreat rates of glaciers on the north-east coast has occurred in the past decade as the climate has continued to warm, and although the glaciers on the south-west side have been slow to respond, their retreat rates may now also be on the increase. The change in mass balance of glaciers is attributed to many other factors including topography, catchment area, glacier width and flow dynamics. This study gives an overview of the main trends observed, but other factors must be taken into account when considering the responses of individual glaciers (e.g. Oerlemans 1989). 

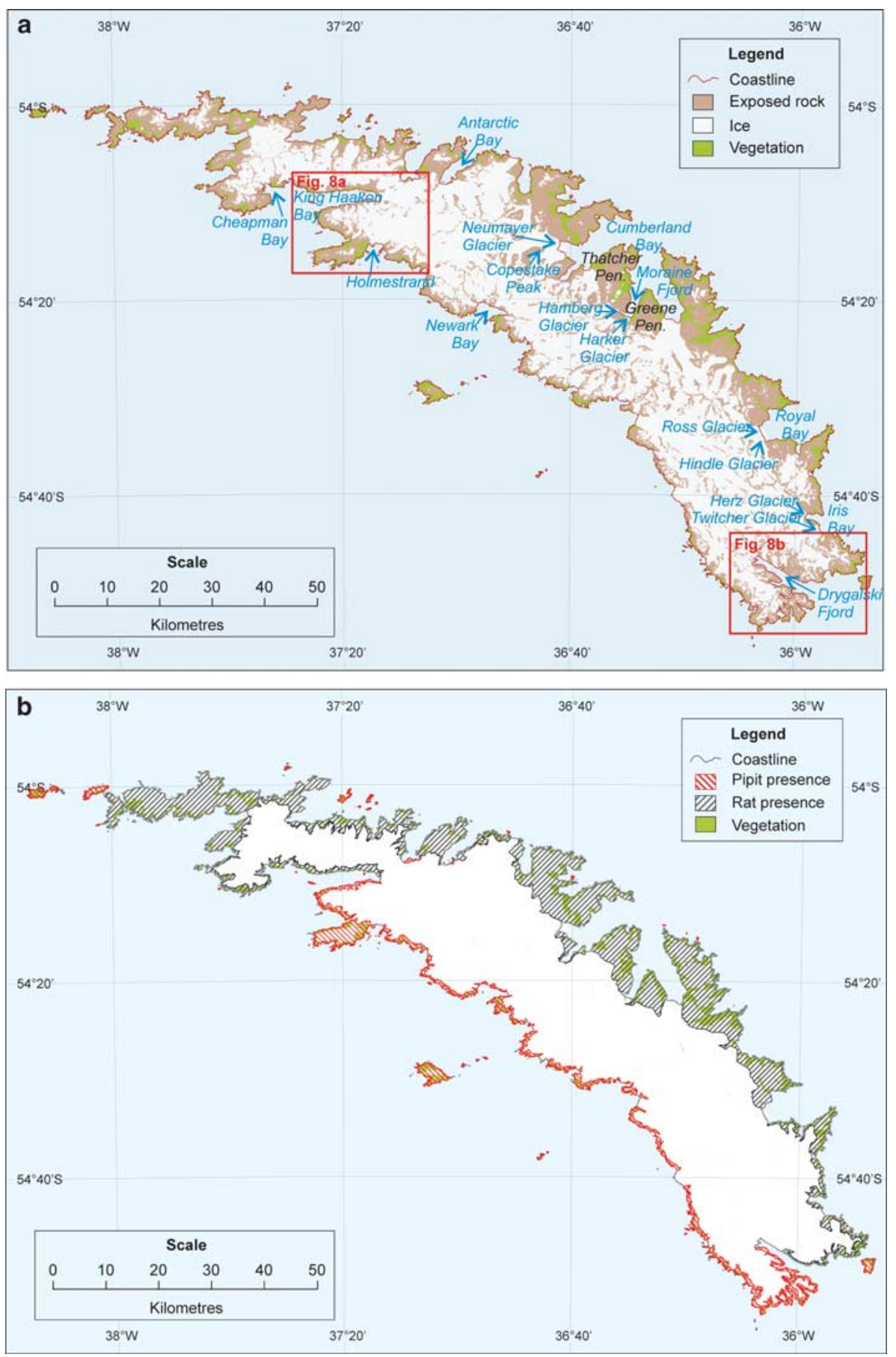

Fig. 6. a. Overview map of South Georgia showing placenames mentioned in text, plus vegetation patterns and land surface. b. The spatial distribution of rats and pipits on South Georgia.

\section{Impact of glacier retreat on the ecosystem}

Invasive species on South Georgia

There are a number of explanations for the presence of invasive species in different regions of South Georgia. The original cause of introduction was the carriage of rats and mice on sealing and whaling vessels, which frequently visited South Georgia between 1775 and 1965 (Poncet 2000). Since their initial introduction, flotsam and sea ice in sheltered bays may have enabled rats to reach rat-free areas, and although swimming is a less likely method of invasion (Pye \& Bonner 1980), rats are known to have swum up to a distance of at least $30 \mathrm{~m}$ in sheltered waters at South Georgia (S. Poncet, observation). Rats colonize and thrive in the suitable habitats on the island. Data held in the SGGIS reveals that $8.6 \%\left(306 \mathrm{~km}^{2}\right)$ of the area of South Georgia $\left(3542 \mathrm{~km}^{2}\right)$ is vegetated (i.e. classified as sparse, partial or full cover) and of this, $73 \%\left(223 \mathrm{~km}^{2}\right)$ is rat-infested. 
Briggs Glacier front:

Total retreat between 1958 and $2006=1.1 \mathrm{~km}$

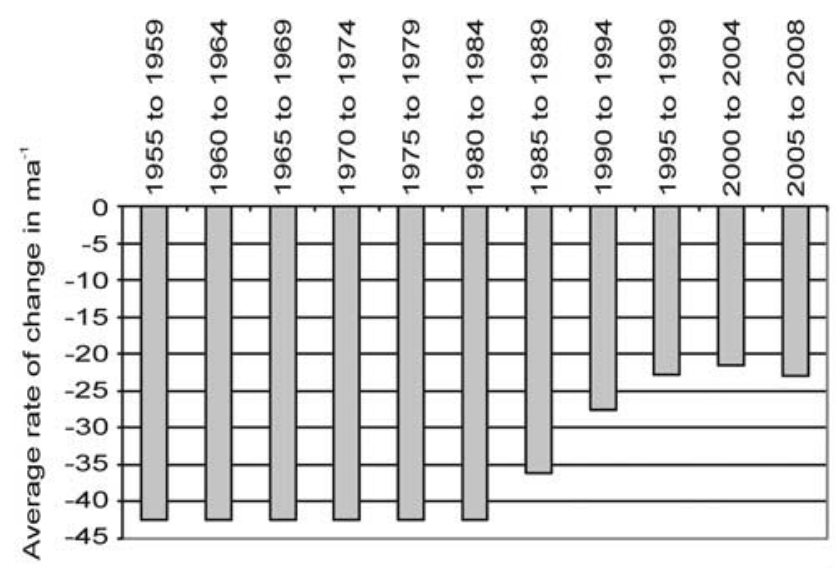

Risting/Jenkins Glacier front: Total retreat between 1958 and $2003=1.8 \mathrm{~km}$

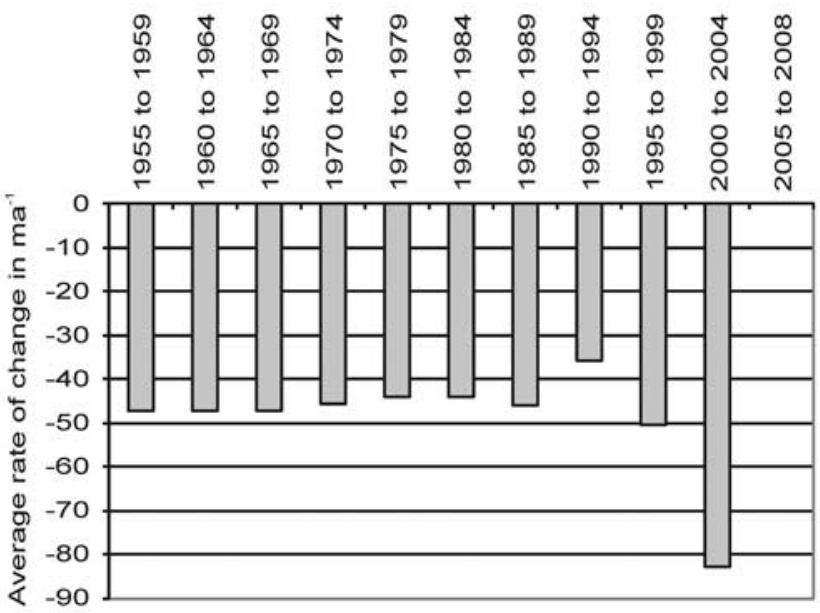

Fig. 7. Changes in Briggs Glacier (King Haakon Bay) and Risting/Jenkins Glacier (Drygalski Fjord).

The occupied areas are primarily along the northern coast, and on the southern coast to the west of Holmestrand, where the climate conditions are more amenable than the exposed southern coast. Tussac grass is essential for the survival of rats on South Georgia (Pye \& Bonner 1980, Poncet 2000), as it is the principal component of their diet and provides nesting material and shelter.

Rat predation on birds and invertebrates that inhabit tussac areas is well documented (Pye \& Bonner 1980, Moors 1985, Prince \& Poncet 1996, Poncet 2000). Surveys at South Georgia have shown that pipits and small burrowing petrels cannot co-exist with rats (probably due to predation on eggs and chicks) and the spread of rats is the probable cause of depletion in numbers of these groundnesting birds on the island (Pye \& Bonner 1980, Prince \& Poncet 1996, McIntosh \& Walton 2000, Poncet 2000,
Pasteur \& Walton 2006). The current distribution of rats is shown in Fig. 6b, alongside the distribution of pipits and areas of vegetation cover. It should be noted that mice probably also affect the ecosystem, as field visits by S. Poncet to Nuñez Peninsula have found that there are mice but no rats present in this vegetated region and yet pipit populations are lower than expected.

Rats do not currently occupy all sections of the coast on South Georgia, because several factors limit their spread. The absence of rats along the south coast can be largely attributed to its harsh climate, which results in an unfavourable habitat for rodents. Rats introduced to this region during the 'Little Ice Age' in the late 18th century (Headland 1984) may not have been able to survive, due to the severity of the climate and the limited food resources. However, with the recent increase in average temperature, there may be areas of this south coast that would now be a habitable environment for rats. This stretch, covering approximately two thirds of the southern coast, is currently occupied by pipits and remains ratfree. Whether it is likely to remain so is discussed in the following section.

\section{Glacial barriers to invasive species}

There is much evidence to suggest that glaciers are extremely effective dispersal barriers (Holdaway 2001, Robertson \& Gemmell 2004). Analysis of the glacier front changes in relation to the other environmental data in the SGGIS reveals a strong spatial link between the presence of rats and the retreat of glaciers.

The two key areas when considering management of rat migration are at the head of King Haakon Bay, near the west end of the island, and in Drygalski Fjord, at the south-east extremity of the island (Fig. 6a). These locations are at either end of the rat free south-west coast and so the glaciers in these regions are currently acting as barriers to rat migration. The results show, however, that they have retreated by over $1 \mathrm{~km}$ in the past 50 years, and are still undergoing retreat (Figs $7 \& 8$ ). Continuing glacial retreat will expose beach (even if only at low tide), create an access route for rat migration to adjoining rat-free areas and lead potentially to extermination of local populations of pipits and burrowing petrels. To determine the likelihood of this scenario we assess the two areas in more detail. In each case, several factors are considered including the rate of retreat of the glacier, glaciological factors such as the long profile of the glacier, indications that its bed at the snout is below or at sea level, and the nature of the vegetation near the glacier barrier.

Case study 1: King Haakon Bay

In King Haakon Bay, Briggs Glacier at the head of the bay separates the area that is colonized by rats from rat free terrain (Fig. 8a). Cape Rosa and Nuñez Peninsula to the south is a major breeding area for pipits and other burrownesting birds. Briggs Glacier has retreated more than $1 \mathrm{~km}$ 

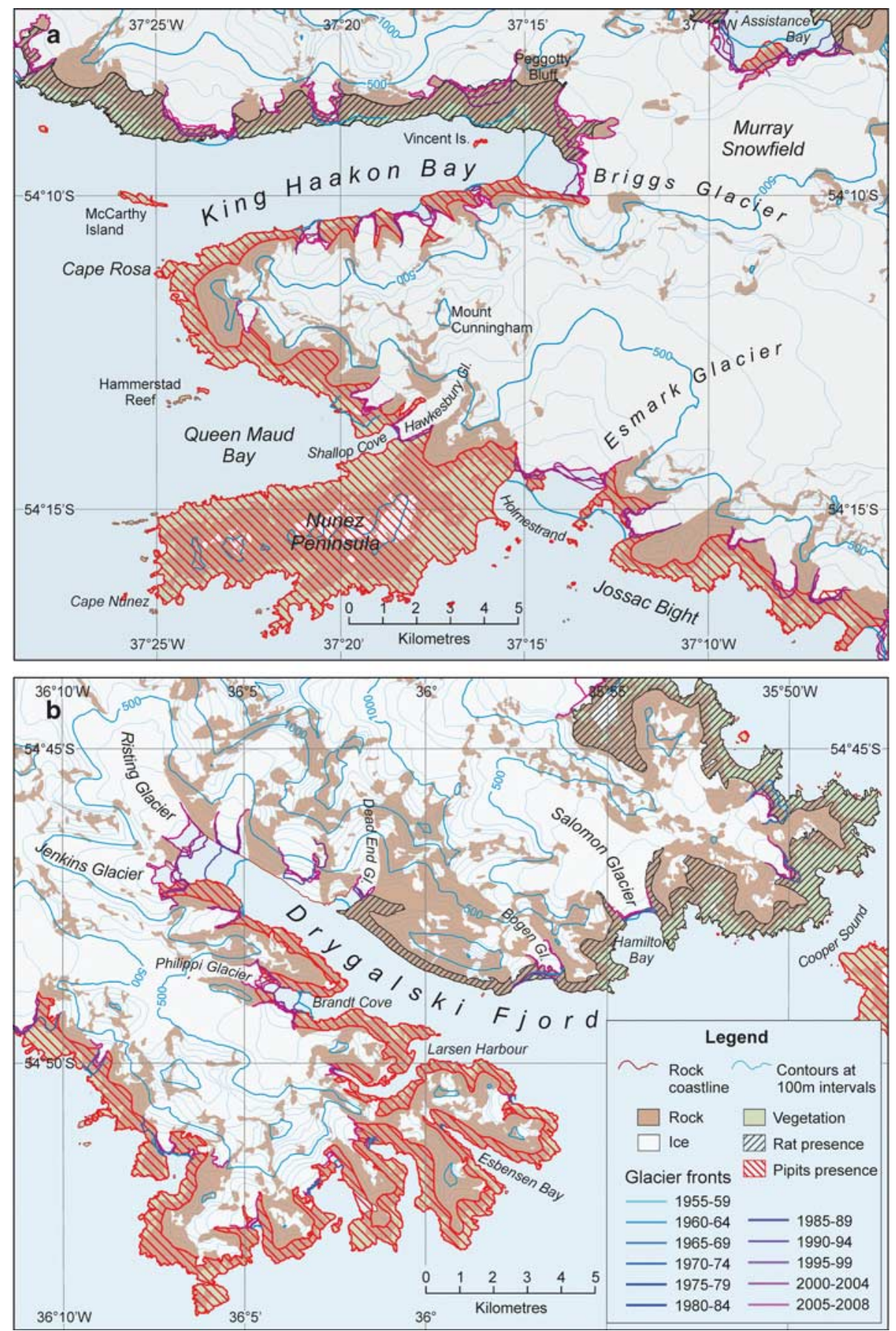

Fig. 8. a. King Haakon Bay. b. Drygalski Fjord.

since 1958, but since 2000 little change is visible, and features of the glacier front are consistent from image to image. The profile of the glacier, based on a Digital Elevation Model derived from Shuttle Radar Topography Mission (SRTM) interferometric radar, is convex upward from the snout, i.e. it is steeper near the snout than further inland. The glaciological indicators suggest that this glacier is currently grounded at or only slightly below sea level. Ice thickness can be estimated from surface slope (Paterson 1981, p. 86) and conservative assumptions give ice thicknesses in the region of $50 \mathrm{~m}$ between the coast and the $100 \mathrm{~m}$ contour. The unchanging nature of the ice front, the estimated ice thickness and the convex upward long profile all suggest that the rapid retreat from 1958-2000 took place in parts of the glacier that were grounded below sea level, but since 2000 the glacier has become grounded at or near sea level. There are also several smaller glaciers on the south shore of King Haakon Bay to the west of Briggs Glacier. They are all less than $1 \mathrm{~km}$ wide and are retreating, and like Briggs Glacier, their snouts appear to be 
grounded at or near sea level. Although vegetation is sparse on the steep south side of the bay (as indicated in the vegetation layer in the SGGIS, derived from the normalized difference vegetation index from a Landsat ETM+ image), there may still be sufficient isolated patches of tussac grass for rats to use as 'stepping stones'. Even minor further retreat of Briggs Glacier and glaciers on the south coast of King Haakon Bay will result in a land pathway to the currently rat-free Cape Rosa area.

If invasion occurs, the next major barrier to rat dispersal would be at Esmark Glacier in Holmestrand. Although there is beach along the snout of the small northern tongue of the glacier, the southern half of Esmark Glacier is an actively calving glacier front. In contrast to Briggs Glacier, Esmark Glacier shows continuing retreat. The long profile of the glacier is also lower than that of Briggs Glacier. These factors suggest that Esmark Glacier is still grounded below sea level, and that there is no immediate danger of rats being able to pass this barrier.

\section{Case study 2: Drygalski Fjord}

In the region around Drygalski Fjord (Fig. 8b), at the other extremity of the rat-free area of the south coast of South Georgia, glacier barriers may not be the only factor inhibiting the spread of rats into currently rat-free areas. Larsen Harbour was extensively used by whalers and sealers, providing many opportunities for rats to be introduced. However, there is very little suitable tussac habitat suitable for rats, and the area is currently rat free. The nearest area occupied by rats is the eastern shore of Drygalski Fjord, and further migration up into the fjord is probably constrained as much by the steep, barren terrain and absence of tussac as it is by glacial barriers. Risting Glacier and Jenkins Glacier at the head of Drygalski Fjord form the major glacier barrier in this region, and in common with other major glaciers, both have shown an accelerating rate of retreat since the mid-1990s. Ice thickness estimates from surface slope indicate ice thicknesses in the region of 100-200 m, so these glaciers are based at or below sea level. Continued retreat will not, therefore, provide a land pathway for rats for some time.

The immediate conclusion is that the combination of glaciological and ecological factors will continue to provide an effective barrier to the migration of rats west of Drygalski Fjord. A greater danger could be presented if the extent of tussac habitat increased due to regional warming; in this case the glacial barriers would become the primary barrier to migration of rats.

\section{Rat management implications}

This study has highlighted that one consequence of glacier retreat on South Georgia is the risk of rats spreading into previously rat-free areas. The presence of mice on Nunez Peninsula shows that the habitat is suitable for small rodents to survive and breed, therefore the absence of rats is not because they cannot survive there but because they have not yet been introduced into the area. This is conclusive evidence that Briggs Glacier is currently acting as a barrier to rats from the north. Our results show that this retreating glacier front is currently grounded at or near sea level; associated with this is a high risk of a gateway opening up to allow rats to spread into a currently rat-free region. The glaciers in Drygaslski Fjord do not appear to currently pose a risk and so action is less critical in this region at present. Although there is no evidence to show that the coast in the vicinity of Briggs Glacier has already become accessible to rats, this study highlights this region as a priority for taking action on the prevention of rat spread. Several courses of action are possible, including the installation of sentinel stations (i.e. gnawsticks) along the coastline west of Briggs Glacier in order to act as an early warning device and to establish current rat distribution in proximity to the glacier margin. Although the timescale for further glacier retreat above sea level cannot be predicted from this study, it highlights this region as a priority for rat eradication or erection of man-made barriers and suggests action should be taken before further ice barriers to rat migration are lost.

\section{Conclusion}

The coastal glaciers on South Georgia show a trend of accelerating retreat over the past fifty years, with the most rapid increase occurring in the past decade. This has occurred simultaneously with the recent period of climate warming that began in the 1950s. The most dramatic changes have occurred along the north-eastern coast, where ten of the thirty-eight glaciers have retreated by over $1 \mathrm{~km}$ in the past 50 years. Of these, Neumayer Glacier has retreated the most: $4.4 \mathrm{~km}$ since 1957. The rates of retreat of these glaciers have also increased, from $8 \mathrm{Ma}^{-1}$ in the $1950 \mathrm{~s}$ to $60 \mathrm{Ma}^{-1}$ since 2005. Although the glaciers along the north-east coast were known to be retreating, our study shows that those along the south-west side have also been retreating throughout the past half-century. Only two of the sixty-five glaciers in this region have advanced. The average rate of retreat of the south-west glaciers throughout this time has been $8 \mathrm{Ma}^{-1}$, with a slight increase since 2000 .

In terms of environmental management, the results for the south-west coast glaciers are of greater significance than those on the north-east coast. Almost all of the habitable northern coastal regions are already occupied by rats and other invasive species. The area of concern is the rat-free south coast, where glaciers previously thought to be stable or advancing are in fact retreating. An increase in rates of retreat of these glaciers has potential to open up new regions for colonization, with consequent increased predation of important breeding populations of ground- and burrow-nesting birds. 
Examination of the retreat rates and long-profiles of glaciers in two key regions on the south coast reveals that the continuing retreat of glaciers in one of these regions, the King Haakon Bay area, presents a real risk of rat spread. Here a land-bridge is likely to form at the snout of Briggs Glacier, allowing potential rat incursion to the area of land to the south, initially as far as Esmark Glacier. The Drygalski Fjord region is of less immediate concern as the glaciers and habitats there remain effective barriers to rat spread, although this may change if current warming trends continue.

Climate change, resulting in more amenable conditions in previously hostile environments (providing better habitat and more food), is a significant factor in opening up new areas for rat colonization. Glacial retreat, however, will provide the pathway to these regions and must be taken into account when calculating the risk of rat spread on South Georgia.

\section{Acknowledgements}

We are very grateful for the three reviewers for their helpful comments and suggestions, which helped us to improve this paper.

\section{References}

Clapperton, C.M., Sugden, D.E., Birnie, J. \& Wilson, M.J. 1989. Late glacial and Holocene glacier fluctuations and environmental change on South Georgia, Southern Ocean. Quaternary Research, 31, 210-228.

Cook, A.J., Fox, A.J., Vaughan, D.G. \& Ferrigno, J.G. 2005. Retreating glacier fronts on the Antarctic Peninsula over the past half-century. Science, 308, 541-544.

Frenot, Y., Chown, S.L., Whinam, J., Selkirk, P.M., Convey, P., Skotnicki, M. \& Bergstrom, D.M. 2005. Biological invasions in the Antarctic: extent, impacts and implications. Biological Reviews, 80, 45-75.

Gordon, J.E. \& Timmis, R.J. 1992. Glacier fluctuations on South Georgia during the 1970s and early 1980s. Antarctic Science, 4, 215-226.

Gordon, J.E., Haynes, V.M. \& HubBard, A. 2008. Recent glacier changes and climate trends on South Georgia. Global and Planetary Change, 60, 72-84.
HAYward, R.J.C. 1983. Glacier fluctuations in South Georgia, 1883-1974. British Antarctic Survey Bulletin, No. 52, 47-61.

Headland, R.K. 1984. The island of South Georgia. Cambridge: Cambridge University Press, 293 pp.

HoldawAy, R.N. 2001. The frequency and potential significance of differences in non-metric skull and mandible morphology in two populations of Norway rat (Rattus norvegicus) separated by glaciers on South Georgia, South Atlantic Ocean. Cambridge: BAS Archives, G84/1/2.

McIntosh, E. \& Walton, D.W.H. 2000. Environmental Management Plan for South Georgia. Cambridge: British Antarctic Survey, on behalf of the Government of South Georgia and the South Sandwich Islands, 105 pp.

MooRs, P.J. 1985. Norway rats (Rattus norvegicus) on the Noises and Motukawao islands, Hauraki Gulf, New Zealand. New Zealand Journal of Ecology, 8, 37-54.

Oerlemans, J. ed. 1989. Glacier fluctuations and climatic change. Proceedings of the Symposium on Glacier Fluctuation and Climate Change held in Amsterdam, 1-5 June 1987. Dordrecht: Kluwer, 414 pp. Pasteur, E.C. \& Walton, D.W.H. 2006. South Georgia: plan for progress. Managing the environment 2006-2010. Cambridge: British Antarctic Survey, for the Government of South Georgia and the South Sandwich Islands, $76 \mathrm{pp}$.

Paterson, W.S.B. 1981. The physics of glaciers, 2nd ed. Oxford: Pergamon, $380 \mathrm{pp}$.

Poncet, S. 2000. Feasibility of rat eradication at South Georgia: a desk study report. Cambridge: BAS Archives, G84/1/1.

Poncet, S., Robertson, G., Phillips, R.A., Lawton, K., Phalan, B., Trathan, P.N. \& Croxall, J.P. 2006. Status and distribution of wandering, black-browed and grey-headed albatrosses breeding at South Georgia. Polar Biology, 29, 772-781.

Prince, P.A. \& Poncet, S. 1996. The breeding and distribution of birds on South Georgia. In Trathan, P.N., Daunt, F.H.J., MurPhy, E.J., eds. South Georgia: an ecological atlas. Cambridge: British Antarctic Survey.

PYE, T. \& Bonner, W.N. 1980. Feral brown rats, Rattus norvegicus, in South Georgia (South Atlantic Ocean). Journal of Zoology, 192, $237-255$

Robertson, B.C. \& Gemmell, N.J. 2004. Defining eradication units to control invasive species. Journal of Applied Ecology, 41, 1042-1048.

Scott, J.J. \& Poncet, S. 2003. South Georgia Environmental Mapping Report. Technical Report No. EBS03/1. South Georgia Environmental Baseline Survey. Cambridge: BAS Archives, G84/1/3.

Turner, J., Colwell, S.R., Marshall, G.J., Lachlan-Cope, T.A., Carleton, A.M., Jones, P.D., Lagun, V., Reid, P.A. \& Jagovkina, J. 2004. The SCAR READER project: towards a high-quality data base of mean Antarctic meteorological observations. Journal of Climate, 17, 2890-2898. 